Boletín de la Sociedad Geológica Mexicana

VOLUMEN 62, NÚM. 3, 2010, P. 453-467

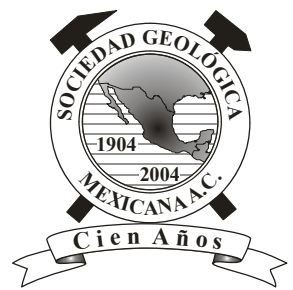

\title{
Last Glacial Maximum deep water masses in southwestern Gulf of Mexico: Clues from benthic foraminifera
}

\author{
Ma. Luisa Machain-Castillo, ${ }^{1, *}$, F. Raúl Gío-Argáez ${ }^{1}$, L. Bárbara Cuesta-Castillo², Javier A. \\ Alcalá-Herrera ${ }^{3}$, Barun K. Sen Gupta ${ }^{4}$ \\ ${ }^{1}$ Instituto de Ciencias del Mar y Limnología, Universidad Nacional Autónoma de México, Circuito Exterior, Cd. Universitaria, \\ México, D.F., 04360, Mexico. \\ ${ }^{2}$ Posgrado en Ciencias del Mar y Limnología, Universidad Nacional Autónoma de México, Circuito Exterior, Cd. Universitaria, \\ México, D.F., 04360, Mexico. \\ ${ }^{3}$ Wilhelm Ibarra Analytical Services, Inc., 1101 Buttercup Circle, College Station, TX 77845, USA. \\ ${ }^{4}$ Department of Geology and Geophysics, Louisiana State University, Baton Rouge, LA 70803-4101, USA. \\ *machain@cmarl.unam.mx
}

\begin{abstract}
The repercussions of climate change during the Last Glacial Maximun (LGM) associated with changes in the structure and chemistry of abyssal waters in the southwestern Gulf of Mexico were studied by numerical analysis of benthic foraminiferal data from three sediment cores (water depth 1988-2735 m). In this context, to better understand the distribution patterns of modern benthic foraminifera in bathyal and abyssal waters of the area, species data from twelve core-tops (water depth 960-3255 m) were also analyzed. Multivariate Q-mode factor analysis separated the modern foraminiferal faunas of the North Atlantic Deep Water (NADW, deeper than $\sim 2000 \mathrm{~m}$ ), dominated by Nuttallides decorata, Alabaminella turgida, Ioanella tumidula, and Globocassidulina subglobosa, from those of the shallower Subantarctic Intermediate Water (AAIW) and Caribbean Midwater (CMW), characterized by the association of Bolivina lowmani, Bulimina aculeata, Alabaminella turgida, Globocassidulina subglobosa, Epistominella exigua, and E. vitrea.

Although most of the species are found in the entire stratigraphic interval studied, detailed examination shows differences between the dominant LGM and Holocene assemblages, which can be traced to climate-related modifications in world ocean circulation in the LGM, particularly those of NADW. During LGM, Alabaminella turgida (a species sensitive to oxygen depletion) along with a group of dissolution-prone species such as Biloculinella irregularis and Cornuloculina inconstans, thrived in the deepest part of the study area, indicating well-oxygenated waters of glacial NADW (GNADW). As the production of GNADW ceased in the Holocene, the deep areas in the Gulf were occupied by the present NADW that contains less oxygen and more $\mathrm{CO}_{2}$. This water mass is more corrosive and precluded the presence of dissolution-prone species during the LGM, except in the most calcium carbonate- and oxygen-rich areas next to the Yucatan platform. Conditions in this area allowed the proliferation of Nuttallides decorata during the Holocene, while the N. decorata and Alabaminella turgida populations decreased in the western Gulf.
\end{abstract}

Keywords: Benthic foraminifera, paleoceanography, Last Glacial Maximum, water masses, southwestern Gulf of Mexico.

\section{Resumen}

Se estudió la repercusión de los cambios climáticos ocurridos durante el Último Máximo Glacial (UMG) en la estructura y química del agua de fondo (1988-2735 m) del suroeste del Golfo de México por medio del análisis numérico de foraminíferos bentónicos en tres núcleos sedimentarios. En este contexto, para entender mejor la distribución de foraminiferos bentónicos modernos en las aguas batiales y abisales del área, se analizaron también los datos de especies en la parte superior de doce núcleos sedimentarios (960$3255 \mathrm{~m}$ de profundidad). Por medio de un análisis multivariado de factores modo $Q$, se delimitaron dos asociaciones principales: 
la asociación dominada por Nuttallides decorata, Alabaminella turgida, Ioanella tumidula y Globocassidulina subglobosa en Agua Profunda Noratlántica (APNA, a profundidades mayores de $2000 \mathrm{~m}$ ) y la asociación de Bolivina lowmani. Bulimina aculeata, Alabaminella turgida, Globocassidulina subglobosa, Epistominella exigua y E. vitrea, característica de profundidades más someras del Agua Antártica Intermedia y el Agua del Caribe.

Aunque la mayoría de las especies se encuentran en todo el intervalo estratigráfico estudiado, el examen detallado de las faunas muestra claras diferencias entre las asociaciones dominantes del UMG y el Holoceno. Dichas diferencias se pueden relacionar con las modificaciones producidas por los cambios climáticos en el UMG en la circulación oceánica global, particularmente con aquellas del APNA. Durante el UMG, Alabaminella turgida (una especie altamente sensitiva a bajas concentraciones de oxígeno disuelto en el agua) y un grupo de especies susceptibles a la disolución tales como Biloculinella irregularis y Cornuloculina inconstans, prosperaron en la parte más profunda del área de estudio, indicando la presencia de las aguas bien oxigenadas de la APNA glacial. Al cesar la producción de esta masa de agua en el Holoceno, las áreas profundas del Golfo de México fueron ocupadas por el APNA actual, con menor contenido de oxígeno y mayor $\mathrm{CO}_{2}$. Esta masa de agua de mayor corrosividad, no permitió la presencia del conjunto de especies poco tolerantes a la disolución presente durante el UMG, excepto en las zonas cercanas a la plataforma de Yucatán, donde se presenta un mayor contenido de oxígeno y carbonato de calcio. Las condiciones en esta área permitieron la proliferación de Nuttallides decorata durante el Holoceno, mientras que las poblaciones de N. decorata y Alabaminella turgida disminuyeron en la parte occidental del Golfo

Palabras clave: Foraminiferos bentónicos, paleoceanografía, Último Máximo Glacial, masas de agua, Golfo de México suroccidental.

\section{Introduction}

The oceans played a major role in climatic changes associated with the last-glacial period. The modification of the thermohaline circulation and, particularly, shifts in the production/distribution of North Atlantic Deep Water (NADW) changed the balance of heat and salt transport, affecting climate on a planetary scale. In the modern ocean, NADW forms in the Greenland, Iceland, Labrador and Norwegian seas, sinks and flows southward into the major basins of the world's oceans. However, due to the extension of the northern ice sheets during the Last Glacial Maximum (LGM), NADW formed southward, altering its structure, physical and chemical properties (i.e. temperature, salinity, oxygen content, nutrient inventory, $\mathrm{CO}_{2}$ ).

The benthic foraminiferal faunas were affected by these changes in glacial NADW. An earlier investigation (Machain-Castillo et al., 1998) reports that less corrosive, $\mathrm{CO}_{2}$-depleted, LGM bathyal and abyssal waters of the Gulf of Mexico and Caribbean Sea supported populations of high$\mathrm{Mg}$-calcitic benthic foraminifera and aragonitic pteropods that are not present in modern sediments. In this paper we examine the entire benthic foraminiferal suite, and compare modern with LGM assemblages in order to assess deepwater variations related to late Pleistocene climatic changes.

Modern benthic foraminifera from the Gulf of Mexico are well known. There have been major studies on their geographic and bathymetric distributions from the 1950s to the 1980s (Phleger and Parker, 1951; Parker, 1954; Pflum and Frerichs, 1976; Culver and Buzas, 1981, 1983; Poag, 1981, 1984). More recently, their relationships with water masses in the northern Gulf have also been investigated (Denne and Sen Gupta, 1991, 1993; Jones and Sen Gupta, 1995; Osterman, 2003). Pleistocene benthic foraminiferal faunas of the Gulf are much less known in spite of several significant studies (Dignes, 1979; Jones and Sen Gupta, 1996; Machain-Castillo et al., 1998; Denne and Sen Gupta, 2003).

\section{Material and methods}

This study is based on (a) 12 core-top samples (960-3255 $\mathrm{m}$ water depth) to delineate the modern faunas in sediments underlying the intermediate and deep water masses, and (b) three gravity cores collected below sill depth (1988-2735 $\mathrm{m}$ ) in the central southwestern Gulf of Mexico to compare LGM assemblages and assess deep-water variations related to Pleistocene climatic changes (Figure 1, Table 1). The JS cores were taken by the Universidad Nacional Autónoma de México from the O/V Justo Sierra and the K cores by the U.S. Naval Oceanographic Office from the USNS Kane. The foraminifera were obtained from $15 \mathrm{cc}$ sediment samples collected at $10 \mathrm{~cm}$ stratigraphic intervals. The sediments were oven dried at $50{ }^{\circ} \mathrm{C}$, weighed, washed through a 63 $\mu \mathrm{m}$ mesh, dried and weighed again. The washed residues were subdivided with the aid of an Otto microsplitter to obtain aliquots of approximately 1000 benthic foraminifers. All species were identified and counted. A Q-mode factor analysis was performed on the species-abundance data with the Statistica 6.0 program (see section 5.1 for detail).

\section{Water masses}

\subsection{Present-day water masses}

The water masses entering the Gulf of Mexico through the Yucatan Channel are modified as they travel towards the west and mix with resident and coastal waters. According 


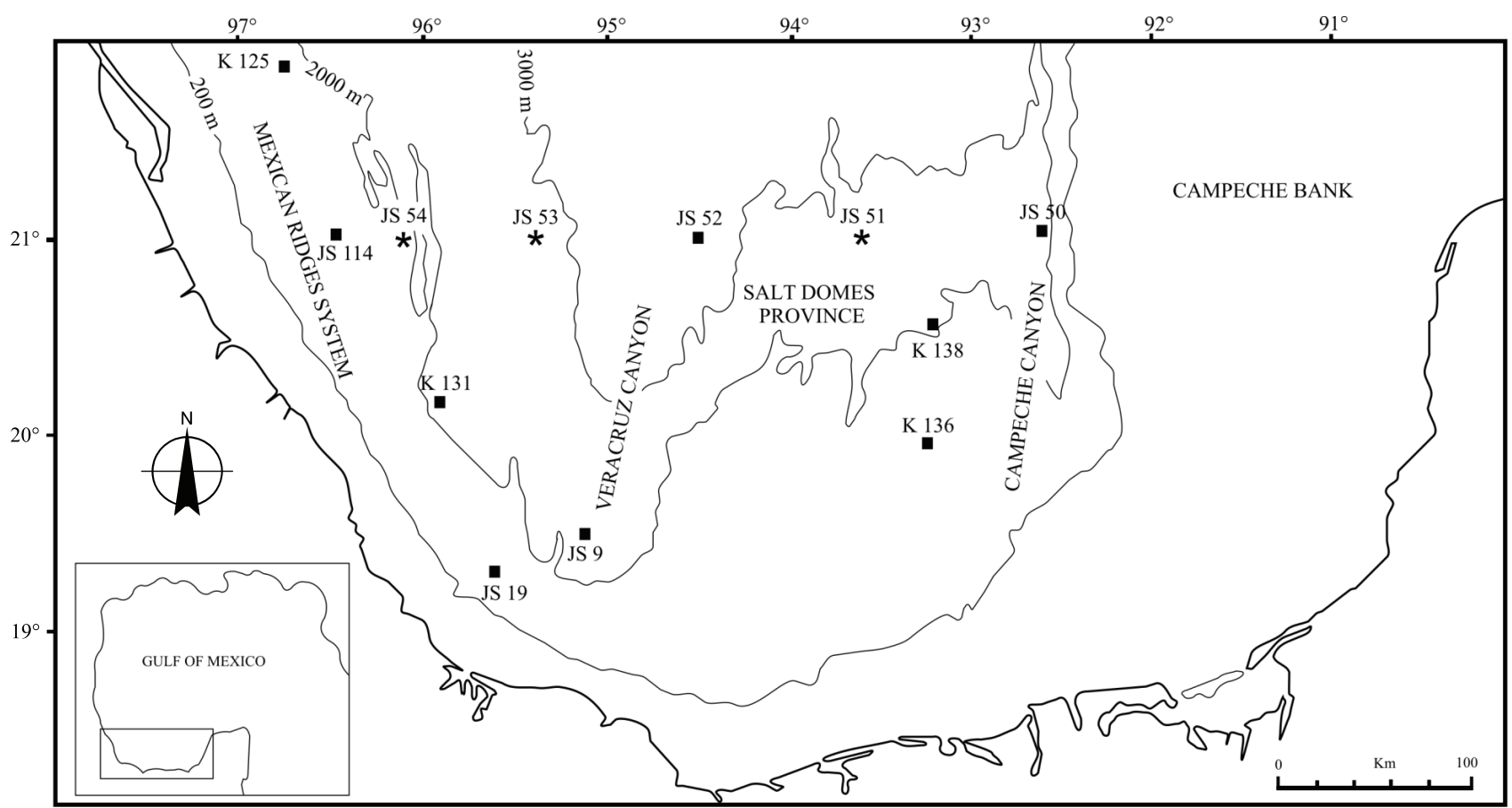

Figure 1. Study area. Squares mark locations of surface (core-top) samples; asterisks mark locations of cores that include Pleistocene sediments (Modified from Martínez-Trápaga, 1990).

Table 1. Locations and depths of core-top and down-core* samples.

\begin{tabular}{lrccc}
\hline $\begin{array}{c}\text { Core } \\
\text { No. }\end{array}$ & Latitude (N) & $\begin{array}{c}\text { Longitude } \\
(\mathrm{W})\end{array}$ & $\begin{array}{c}\text { Water depth } \\
(\mathrm{m})\end{array}$ & $\begin{array}{c}\text { Core length } \\
(\mathrm{cm})\end{array}$ \\
\hline JS114 & $21^{\circ} 00.0^{\prime}$ & $96^{\circ} 37.4^{\prime}$ & 960 & \\
JS19 & $19^{\circ} 21.0^{\prime}$ & $95^{\circ} 38.1^{\prime}$ & 980 & \\
K136 & $19^{\circ} 58.9^{\prime}$ & $93^{\circ} 15.0^{\prime}$ & 1215 & \\
K125 & $21^{\circ} 50.0^{\prime}$ & $96^{\circ} 38.0^{\prime}$ & 1245 & \\
K138 & $20^{\circ} 31.0^{\prime}$ & $93^{\circ} 13.5^{\prime}$ & 1711 & \\
JS54 & $21^{\circ} 00.0^{\prime}$ & $96^{\circ} 06.1^{\prime}$ & 1988 & 130 \\
K131 & $20^{\circ} 11.2^{\prime}$ & $95^{\circ} 59.3^{\prime}$ & 2001 & \\
JS9 & $19^{\circ} 30.4^{\prime}$ & $95^{\circ} 18.3^{\prime}$ & 2117 & \\
JS50 $^{\circ}$ & $21^{\circ} 00.0^{\prime}$ & $92^{\circ} 42.0^{\prime}$ & 2240 & \\
JS51 $^{*}$ & $20^{\circ} 59.9^{\prime}$ & $90^{\circ} 09.9^{\prime}$ & 2680 & 130 \\
JS53 $^{*}$ & $20^{\circ} 59.7^{\prime}$ & $95^{\circ} 24.1^{\prime}$ & 2735 & 160 \\
JS52 $^{2}$ & $20^{\circ} 59.9^{\prime}$ & $94^{\circ} 30.2^{\prime}$ & 3255 & \\
\hline
\end{tabular}

to Aldeco-Ramírez et al. (2009) three water masses are found in the upper $120 \mathrm{~m}$ : Gulf Common Water (GCW) with $\mathrm{T} \sim 22.5^{\circ} \mathrm{C}, \mathrm{S} 36.3-36.4$ (Vidal et al., 1994), Caribbean Tropical Surface Water (CTSW) with T $>28^{\circ} \mathrm{C}, \mathrm{S}>36.4$, and the deeper Caribbean Subtropical Underwater (CSUW) with T 22.2-26 ${ }^{\circ} \mathrm{C}, \mathrm{S} 36.4-36.7$ (Schroeder et al., 1974). In the eastern part of the Gulf, CSUW (also reported as Subtropical Underwater or Tropical Water) is present to depths of $150-250 \mathrm{~m}$ (salinity maximum $\sim 36.7$ at $\mathrm{T} \sim 23$ ${ }^{\circ} \mathrm{C}$ ), whereas in the western Gulf, the Gulf Water (GW, salinity $36.4-36.5$ ) is found to $\sim 250 \mathrm{~m}$ (Morrison et al.,
1983). Around the Yucatan Channel, Kinard et al. (1974) and Rivas et al. (2005) report sporadic occurrences of the Sargasso Sea Water $\left(18^{\circ} \mathrm{C}, \mathrm{S} \sim 36.3\right.$, oxygen maximum $\sim 3.4 \mathrm{ml} \mathrm{L}^{-1}$ ) between $200-400 \mathrm{~m}$, while its presence in the loop current and adjacent anticyclonic rings is reported by Morrison and Nowlin (1977) and Morrison et al. (1983). The next underlying water mass, the Tropical Atlantic Central Water (TACW) with its associated oxygen minimum (2.5$2.9 \mathrm{ml} \mathrm{L}^{-1}$ ), also called Oxygen Minimum Water (OMW), is found down to $\sim 600-700 \mathrm{~m}$ (Nowlin, 1972; Vidal et al., 1994; Rivas et al., 2005). At $\sim 600-1000 \mathrm{~m}$, a remnant of the Antarctic Intermediate Water, or Subantarctic Intermediate Water, is found (AAIW, or SAIW) with salinity minimum $\sim 34.8, \mathrm{~T} \sim 7{ }^{\circ} \mathrm{C}$ (Vidal et al., 1994; Rivas et al., 2005). At depths greater than about $1000 \mathrm{~m}$, Upper NADW enters the Gulf of Mexico via the Caribbean basins. Sill depth of about $1900 \mathrm{~m}$ prevents deeper NADW from entering the Gulf. Within the Gulf, the upper part of this NADW is mixed with Caribbean Intermediate Water (CIW), also called Caribbean Midwater (CMW), which has a slightly lower salinity and higher silicate content than pure NADW (Morrison et al., 1983; Metcalf, 1976; Vidal et al., 1994). Below about 1100-1400 m, high-oxygen NADW (salinity $<35, \sim 4{ }^{\circ} \mathrm{C}$ ) or Gulf Basin Water (GBW) fills the entire basin. McLellan and Nowlin (1963) show that potential temperature and salinity distributions below $1500 \mathrm{~m}$ are uniform; however, dissolved oxygen content decreases away from the Yucatan Channel (Rivas et al., 2005). 


\subsection{Last Glacial Maximum NADW}

Today the deepest water mass entering the Gulf of Mexico is derived from the upper NADW that enters the Caribbean Sea (sill depth $1900 \mathrm{~m}$ ) and the Gulf of Mexico via the Yucatan Channel, with a sill depth of $2040 \mathrm{~m}$ (Rivas et al., 2005). However, paleoceanographic reconstructions by several authors (with various proxies) indicate that during LGM two distinct water masses occurred in the depth range presently occupied by NADW, with the boundary at about 2-2.5 km depth. The shallower one contained fewer nutrients and less $\mathrm{CO}_{2}$ than the present NADW, and the deeper one was nutrient- and $\mathrm{CO}_{2}$-enriched (Curry et al., 1988; Duplessy et al., 1988; Haddad and Droxler, 1996; Boyle, 1997; Marchitto and Broecker, 2006; Lynch-Stieglitz et al., 2007). Thus, the glacial bathyal and abyssal waters of the Gulf of Mexico were depleted in nutrients and $\mathrm{CO}_{2}$ compared to the present ones.

\section{Stratigraphic framework}

Machain-Castillo et al. (1998) delineated the stratigraphic framework and boundaries for the cores in the present study, using the standard planktonic foraminiferal zonation and chronology for the Gulf of Mexico (Kennett and Huddlestun, 1972; Kennett et al., 1985; Flower and Kennett, 1990), as well as the oxygen-isotope record of Globigerinoides sacculifer in core JS 54. Following Kennett and Huddlestum (1972), they recognized the upper part of the Y zone (Y2 and Y1) by high frequencies of Globorotalia crassaformis and Globigerina falconensis, and the virtual absence of Pulleniatina obliquiloculata. All cores reached the Pleistocene subzone Y2, which is correlated with Marine Isotope Stage 2 (Kennett and Huddlestum, 1972); thus the basal portion of the cores represents the LGM.

The Y2-Y1 boundary was recognized by the last consistent occurrence of Globorotalia inflata, the increase of G. crassaformis and Globigerinoides ruber, and the sporadic low frequencies of the Globorotalia menardii group. The Y1 subzone was recognized by high frequencies of Neogloboquadrina dutertrei and G. ruber, low frequencies of $G$. crassaformis and the virtual absence of $G$. inflata. This subzone represents the incursion of meltwater from the Laurentide Ice Sheet into the Gulf from 16 to $11.6 \mathrm{kyrs}$ B.P. (Flower and Kennett, 1990).

The Pleistocene-Holocene boundary (Y-Z, $11 \mathrm{ka})$ and subzone Z2 were recognized by the consistent presence of G. menardii (Holocene) and an abrupt change in $\delta^{18} \mathrm{O}$ values of Globigerinoides ruber (Figure 2). The $\mathrm{Y} / \mathrm{Z}$ boundary is at about $55 \mathrm{~cm}$ in JS-51, $65 \mathrm{~cm}$ in JS-53, and $75 \mathrm{~cm}$ in JS-54. The $\mathrm{Z}$ zone is characterized by the presence of warm water forms ( $G$. menardii and P. obliquiloculata) and the absence of cool water forms ( $G$. inflata and G. falconensis), with the highest frequencies of $G$. menardii and P. obliquiloculata during the Z1 subzone, from 6 kyrs B.P. to Present (Kennett et al., 1985).

\section{Benthic foraminifera}

\subsection{Separation into factors}

The core-top sediments contain 70 species of benthic foraminifera, most of which occur in very low abundances. To delineate the main associations, and avoid the noise due to sporadic or reworked species, only the species that were present in at least three samples and constituted at least $1 \%$ of the assemblage in one sample were used in the Q-mode factor analysis (Appendix 1). We selected a twofactor solution ( $79 \%$ of total variance) because it better explains the data and separates the intermediate water faunas (shallower than $\sim 2000 \mathrm{~m}$ ) from the deeper ones (Tables 2, 3). Although a three-factor solution increased the total explained variance to $90 \%$, the third factor only separated those samples from the NADW that contained reworked shallower water species (i.e. JS 9, JS 50, K138). Other authors using a cutoff similar to ours $(\sim 80 \%$ of total variance) are Nomura (1991), Jian and Wang (1997), Schmiedl et al. (1997) and Murgese and De Deckker (2007).

\subsection{Factor 1}

The core-top Factor 1(F $1 \mathrm{c}-\mathrm{t})$ assemblage is dominated by Bolivina lowmani, Bulimina aculeata, Alabaminella turgida, Globocassidulina subglobosa, Epistominella exigua, and E. vitrea (Figure 3, Table 3), and is represented in core-tops from 960-1711 m water depth, and also in cores JS $9(2711 \mathrm{~m})$ and JS $50(2680 \mathrm{~m})$. Core JS 9 was taken from the western flank of the Veracruz Canyon, and JS 50 from the west of the Campeche Canyon (Figure 1); the presence of shelf species (e.g., Elphidium spp., Figure 3c) and species of Factor 1 assemblage in these cores indicates slumped material in the sediment. The bathymetric ranges and environments of these species in the Gulf of Mexico and Caribbean Sea have been reported by various authors. Bolivina lowmani seems to have a wide tolerance to environmental parameters; it is widely distributed and has a meroplanktonic stage that helps dispersal. Its reported depth range in the Gulf of Mexico is 0-3632 $\mathrm{m}$ (Sen Gupta et al., 2009). Denne and Sen Gupta $(1991,1993)$ find it a common species in the 820-1341 m range, and Jones and Sen Gupta (1995) report it as one of the most abundant species in the 2700-3900 m range in the northwestern Gulf. Bulimina aculeata has been reported from 55 to $3200 \mathrm{~m}$ in the Gulf (Sen Gupta et al., 2009), but it is most abundant in the lower bathyal region (Phleger and Parker, 1951; Pflum and Frerichs, 1976). Denne and Sen Gupta (1991) report it as one of the main components of their CMW assemblage. Alabaminella turgida also has a large depth range (1-3850 $\mathrm{m}$; Sen Gupta et al., 2009), but it is more abundant in the abyssal waters of the Gulf, especially in well-oxygenated 
Relative abundance (\%)
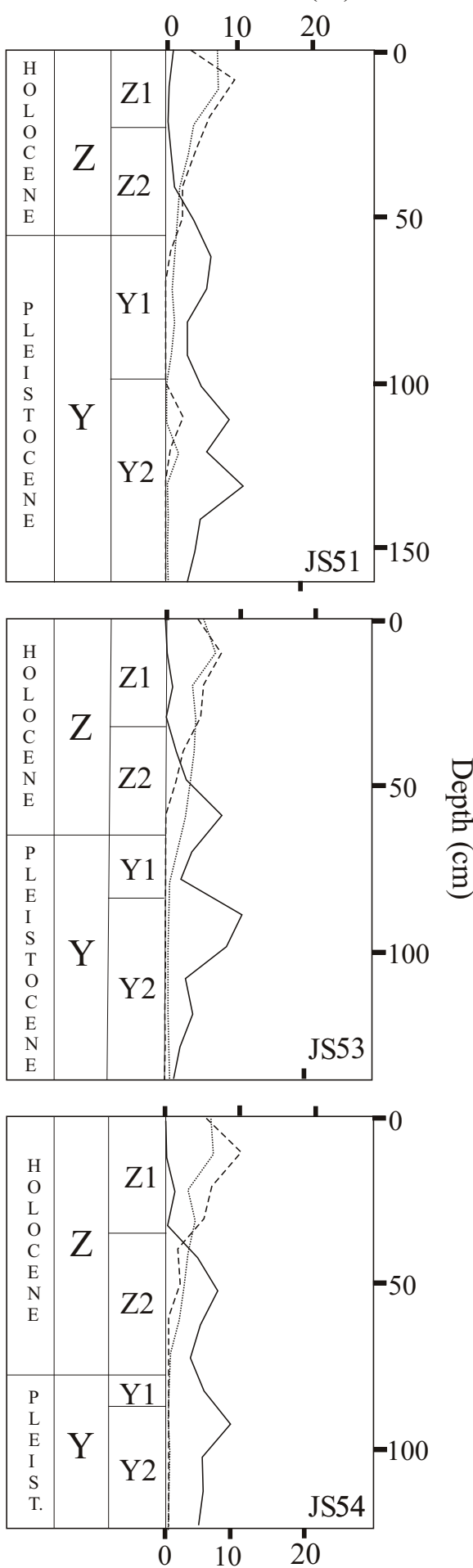

Relative abundance

Planktonic foraminifera (\%)

\section{- Globorotalia crassaformis \\ -... Pulleniatina obliquiloculata \\ ---- Globorotalia menardii}

Figure 2. Left: Biostratigraphic zonation in cores JS51, JS53, and JS54. Right: $\delta^{18} \mathrm{O}$ curve for Globigerinoides ruber in core JS54 (Modified from MachainCastillo et al., 1998)

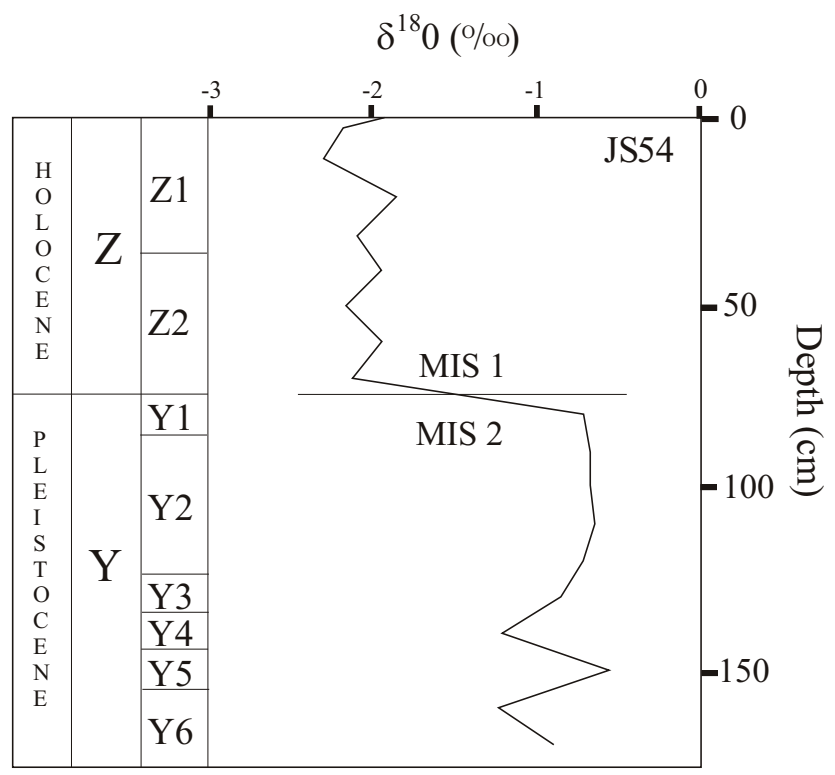

$\frac{\underset{D}{O}}{\stackrel{\Xi}{E}}$ 
Table 2. Eigenvalues and factor loadings for core-top samples.

\begin{tabular}{ccccc}
\hline & Eigenvalue & $\begin{array}{r}\text { \% Total } \\
\text { variance }\end{array}$ & $\begin{array}{c}\text { Cumulative } \\
\text { eigenvalue }\end{array}$ & $\begin{array}{c}\text { Cumulative } \\
\%\end{array}$ \\
\hline 1 & 7.45173 & 62.09775 & 7.45173 & 62.09775 \\
2 & 2.047987 & 17.06656 & 9.499717 & 79.16431 \\
\hline
\end{tabular}

Factor Loadings (Varimax normalized) Extraction: Principal components

\begin{tabular}{lcc}
\hline & Factor 1 & Factor 2 \\
\hline JS9 & 0.818327 & 0.372051 \\
JS19 & 0.858388 & 0.039756 \\
K131 & 0.370763 & 0.901973 \\
K136 & 0.891491 & 0.119481 \\
K125 & 0.700796 & 0.123143 \\
K138 & 0.667599 & 0.621318 \\
JS114 & 0.772131 & 0.441085 \\
JS54 & 0.514242 & 0.84918 \\
JS51 & -0.177407 & 0.829354 \\
JS50 & 0.711386 & 0.475975 \\
JS53 & 0.454662 & 0.875396 \\
JS52 & 0.149038 & 0.794799 \\
\hline
\end{tabular}

waters, with frequencies as high as $20 \%$ (Phleger and Parker, 1951; Parker, 1954; Pflum and Frerichs, 1976). Denne and Sen Gupta (1993) report that it is associated with a group of species sensitive to low concentrations of dissolved oxygen and better represented away from the influence of the Mississippi River Delta. The species is common in the Caribbean but typically shows lower frequencies (Galluzzo et al., 1990). Globocassidulina subglobosa is regarded as a cosmopolitan and eurybathyal species, resistant to dissolution (Dignes, 1979; Denne and Sen Gupta, 1991). Epistominella exigua is widely distributed in the northern Gulf, except around the Mississippi River Delta. It has been reported from 2 to $3700 \mathrm{~m}$ (Sen Gupta et al., 2009) with the highest frequencies generally between $500-1000 \mathrm{~m}$ (Phleger and Parker, 1951; Parker, 1954; Pflum and Frerichs, 1976). Denne and Sen Gupta $(1991,1993)$ consider it to be a characteristic species in AAIW (650-1000 m). The depth range of Epistominella vitrea in the Gulf is 1-3632 m (Sen Gupta et al., 2009). Parker (1954) and Osterman (2003) find the species more abundant above $100 \mathrm{~m}$ and off the Mississippi River Delta. Besides the species with highest scores on Factor 1c-t, Bolivina albatrossi, Bulimina alazanensis, B. mexicana, Gyroidinoides polius, and Osangularia culter are more abundant in samples related to this factor than in deeper samples (Figures $3 \mathrm{~d}, 3 \mathrm{e}$ ). The wide-ranging $B$. albatrossi is most abundant in middle and lower bathyal environments (Phleger and Parker, 1951; Pflum and Frerichs, 1976). Bulimina alazanensis has been found in the Gulf from 42 to $3640 \mathrm{~m}$ (Sen Gupta et al., 2009), and is most abundant in middle bathyal environments (Phleger and Parker, 1951; Pflum and Frerichs, 1976). Bulimina mexicana is known to be associated with the
Table 3. Factor scores for core-top samples.

Factor Scores (Varimax normalized) Extraction: Principal components

\begin{tabular}{lrr}
\hline Species & Factor 1 & \multicolumn{1}{c}{ Factor 2} \\
\hline Alabaminella turgida & 1.54681 & 2.29915 \\
Bolivina albatrossi & 0.92765 & -0.8929 \\
B. lowmani & 4.3341 & 2.8112 \\
B. ordinaria & 0.26811 & -0.4704 \\
Bulimina aculeata & 1.70276 & -1.12526 \\
B. alazanensis & 0.43242 & -0.60811 \\
B. mexicana & 0.78418 & -0.75732 \\
Globocassidulina subglobosa & 1.35106 & -0.1366 \\
Cassidulina neocarinata & -0.56123 & -0.12679 \\
C.nocrossi australis & -0.43871 & -0.17515 \\
G. cf.subglobosa & -0.28406 & -0.08476 \\
Cibicides wuellerstorfi & -0.47839 & 0.06455 \\
Cibicidoides sp & -0.44291 & -0.03866 \\
C pachydermus & -0.01445 & -0.43852 \\
Coryphostoma subspinencis & -0.43539 & -0.0989 \\
Eggerella bradyi & -0.48734 & -0.05847 \\
Elphidium discoidale & -0.50019 & -0.16772 \\
E sp. 1 & -0.44391 & -0.16104 \\
Epistominella exigua & 1.14976 & -0.87946 \\
E. vitrea & 1.03069 & -0.58951 \\
Gavelinopsis tranluscens & -0.2906 & -0.26801 \\
Glomospira charoides & 0.40678 & -0.27906 \\
Gyroidina altiformis & -0.52845 & -0.12233 \\
G. polius & -0.18983 & -0.22452 \\
G. regularis & -0.31505 & -0.28685 \\
G. sp 1 & -0.55477 & -0.12455 \\
G. sp 2 & -0.17726 & -0.21015 \\
Hoeglundina elegans & -0.54949 & 0.08174 \\
Ioanella tumidula & -0.97852 & 1.12121 \\
Neocorbina sp & -0.50165 & -0.14997 \\
Neocrosbya minuta & -0.54587 & -0.20941 \\
Nonionella sp & -0.43061 & -0.16485 \\
Nuttalides decorata & -2.07369 & 4.6269 \\
Oridorsalis sp & -0.48362 & -0.10688 \\
Osangularia culter & 0.51185 & -0.4993 \\
Planulina exorna & -0.51518 & -0.17688 \\
Pullenia subspherica & -0.36245 & -0.11168 \\
P. sp & -0.38538 & -0.20578 \\
Quinqueloculina venusta & -0.71844 & 0.17673 \\
Q. sp 7 & -0.63882 & -0.03695 \\
Sphaeroidina bulloides & -0.25687 & -0.34214 \\
Uvigerina lavéis peregrina & -0.54501 & -0.16009 \\
\hline & -0.69247 \\
\hline
\end{tabular}

OMZ (Oxygen Minimum Zone; 350-550 m; Denne and Sen Gupta, 1991). Parker (1954) records the maximum abundance of Gyroidinoides polius (range 99-3850 m; Sen Gupta et al., 2009) at 2788 m, and Denne and Sen Gupta (1991, 1993) consider it a species associated with CMW. Osangularia culter is found in much of the northern Gulf, except around the Mississippi River Delta, at depths greater than $400 \mathrm{~m}$, with higher frequencies above $2000 \mathrm{~m}$ (Phleger and Parker, 1951; Parker, 1954; Pflum and Frerichs, 1976).

Overall, the assemblage associated with Factor 1 


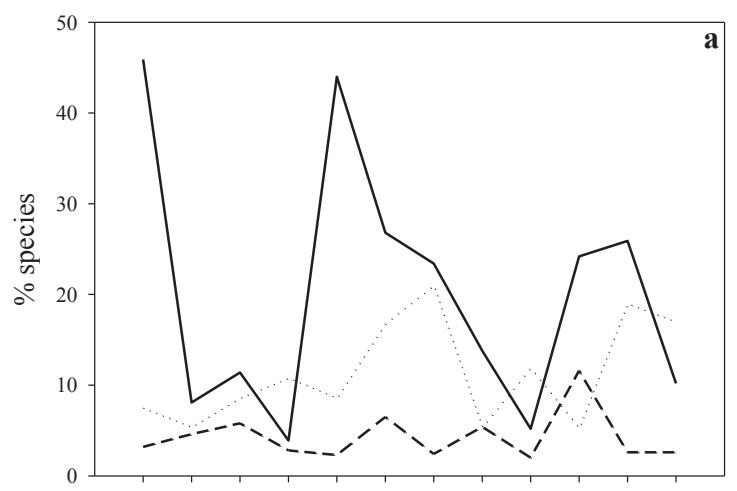

JS114JS19 K136K125K138 JS54 K131 JS9 JS51 JS50 JS53 JS52
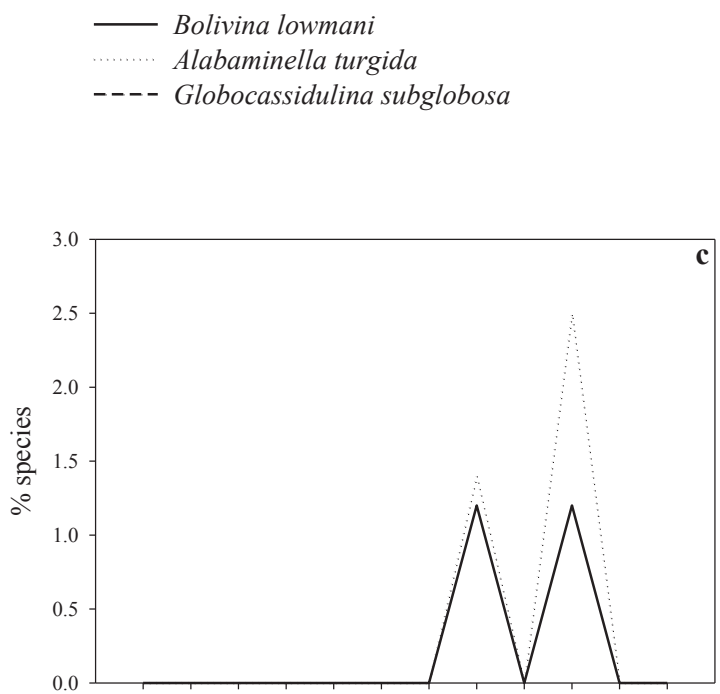

JS114JS19 K136K125K138 JS54 K131 JS9 JS51 JS50 JS53 JS52 Core Tops

Elphidium discoidale Elphidium sp 1

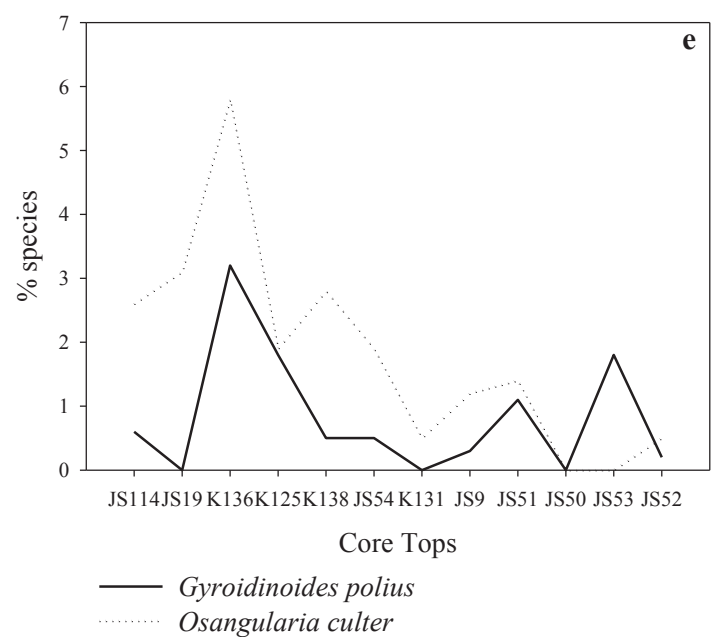

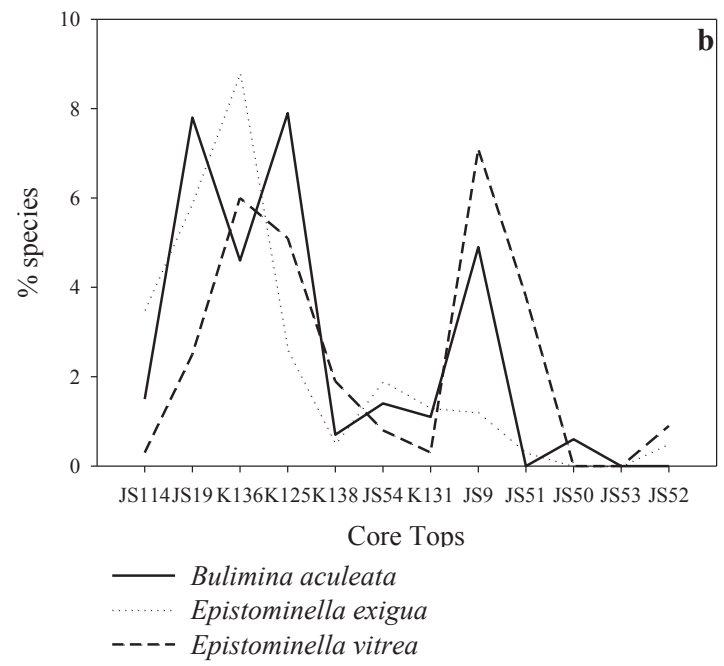

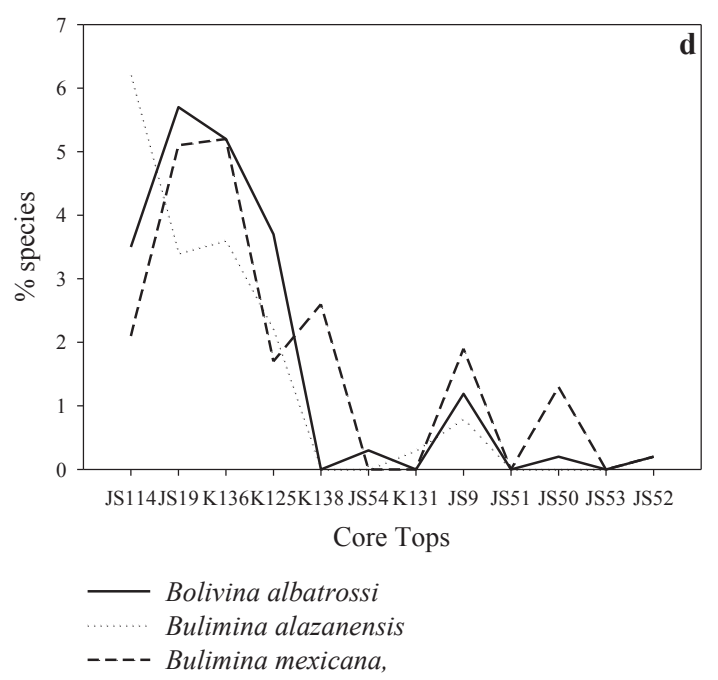

Figure 3. Core-top distribution of Factor 1 assemblage. a) Bolivina lowmani, Alabaminella turgida, Globocassidulina subglobosa; b) Bulimina aculeata, Epistominella exigua, Epistominella vitrea; c) Elphidium discoidale and Elphidium $\mathrm{sp} 1$; d) Bolivina albatrossi, Bulimina alazanensis, Bulimina mexicana; e) Gyroidinoides polius, Osangularia culter. 
c-t is similar to the northwestern Gulf assemblage that straddles the AAIW-CMW boundary (Table 4). Our inability to differentiate the AAIW and CMW foraminiferal assemblages may be partly related to the small number of core-top samples, but the distinction is unclear even in the larger data sets of Culver and Buzas (1983), Denne and Sen Gupta (1991), and Osterman (2003). They suggest that the difference between these water masses may not be sharp, because the Gulf AAIW has been modified in its trajectory and it is only a remnant of the original water mass.

\subsection{Factor 2}

The Factor 2 c-t assemblage is typical of the 1988-3255 m core-top samples and cores JS 9 and JS 50, all collected from below the sill depth. The species with highest scores $(>1)$ on this factor are: Nuttallides decorata, Bolivina lowmani, Alabaminella turgida and Ioanella tumidula (Figure 4). Nuttalides decorata, A. turgida, I. tumidula, and Globocassidulina subglobosa have been reported as predominant taxa in the deep Gulf of Mexico (Phleger and Parker, 1951; Phleger, 1960; Dignes, 1979) and the Caribbean (Gaby and Sen Gupta, 1985; Bertrand, 1986; Galluzzo et al., 1990). Nuttallides decorata has been reported from 155 to $3850 \mathrm{~m}$ in the Gulf of Mexico (Sen Gupta et al., 2009); it is generally considered as typical of bathyal or abyssal waters (Phleger and Parker, 1951; Phleger, 1960; Pflum and Frerichs, 1976). Dignes (1979) suggests its distribution could be partly controlled by calcite dissolution, since its relative abundances (particularly down-core) increase in areas of low-carbonate dissolution. Denne and Sen Gupta (1993) report the occurrence of $N$. decorata from 1204 to $1361 \mathrm{~m}$ (their deepest sample) and consider it characteristic of the CMW (1000-1500 m). The reported depth range of Ioanella tumidula in the Gulf is 68-
3850 m (Sen Gupta et al., 2009). Phleger and Parker (1951) record its highest abundances below $2000 \mathrm{~m}$, and Pflum and Frerichs (1976) find an abundance increase with depth (> $10 \%$ at $>3300 \mathrm{~m}$ in the central and western Gulf). In the study area, its frequencies are $<2 \%$ above $2700 \mathrm{~m}, 6 \%$ at $2735 \mathrm{~m}$, and $17 \%$ at $3255 \mathrm{~m}$. In the Grenada, Venezuela, and Colombia basins, I. tumidula is known from 1000-4000 $\mathrm{m}$, increasing in abundance with water depth; a maximum value of $13 \%$ is recorded at $4000 \mathrm{~m}$ in the Colombia Basin (Gaby and Sen Gupta, 1985; Bertrand, 1986; Galluzzo et al., 1990). Hoeglundina elegans and Cibicides wuellerstorfi also show maximum abundances in the Factor $2 \mathrm{c}$-t assemblage (Figure 4b). Phleger (1960) considers them as characteristic of the lower continental slope and deep sea, along with $N$. decorata, I. tumidula, and A. turgida. Denne and Sen Gupta (1991, 1993) recognize $C$. wuellerstorfi as a characteristic species of their deepest assemblage (CMW, 1000-1500 m) in the northwestern Gulf.

\subsection{Down-core distributions}

To delineate changes in foraminiferal assemblages in waters below sill depth during the late Pleistocene (LGM and deglaciation), we looked at the down-core distribution of factors and species in 3 cores along $21^{\circ} \mathrm{N}$ (JS 54, JS 53, JS 51; 1988-2735 m; Appendix 2). A core that contains reworked material (JS 50) and one that did not reach the Pleistocene (JS52) were not used.

Factor analysis of down-core foraminiferal data produces 3 factors that explain $97.8 \%$ of the total variance (Tables 5, 6, 7). Down-core Factor 1 (F 1 d-c) accounts for $82.4 \%$ of the total variance; only two species show positive scores: Nuttallides decorata, with 6.08 and Oridorsalis sp. 1 with 0.09 (Figure 5). The species with strongest negative scores are Bolivina lowmani (-0.98), Alabaminella turgida

Table 4. Comparison of benthic foraminiferal assemblages for the slope and abyssal water masses in the Gulf of Mexico (mwd = meters water depth).

\begin{tabular}{|c|c|c|c|}
\hline Culver and Buzas, 1983 & Osterman, 2003 & Denne and Sen Gupta, 2003 & This paper \\
\hline \multirow[t]{2}{*}{ Bathyal and abyssal } & Bathyal & $\begin{array}{l}\text { Subantactic Intermediate Water } \\
\text { (SAIW) }\end{array}$ & AAIW + CMW \\
\hline & $640-1020(\mathrm{mwd})$ & 671-1000 (mwd) & $960-1700(\mathrm{mwd})$ \\
\hline Laticarinina pauperata & Laticarinina pauperata & Epistominella exigua & Bolivina lowmani \\
\hline Cyclamina cancellata & Bulimina aculeata & Osangularia rugosa & Bulimina aculeata \\
\hline \multirow[t]{9}{*}{ Osangularia culter } & Cyclamina cancellata & Osangularia culter & Alabaminella turgida \\
\hline & Osangularia culter & Bulimina alazanensis & Globocassidulina subglobosa \\
\hline & Gyroidina neosoldanii & Uvigerina peregrina dirupta & Epistominella exigua \\
\hline & & & Epistominella vitrea \\
\hline & & Caribbean Midwater (CMW) & NADW (GBW) \\
\hline & & $1000-1500(\mathrm{mwd})$ & $1988-3255$ (mwd) \\
\hline & & Gyroidinoides laevis & Nuttalides decorata \\
\hline & & Bulimina aculeata & Bolivina lowmani \\
\hline & & Nuttalides decorata & Alabaminella turgida \\
\hline
\end{tabular}



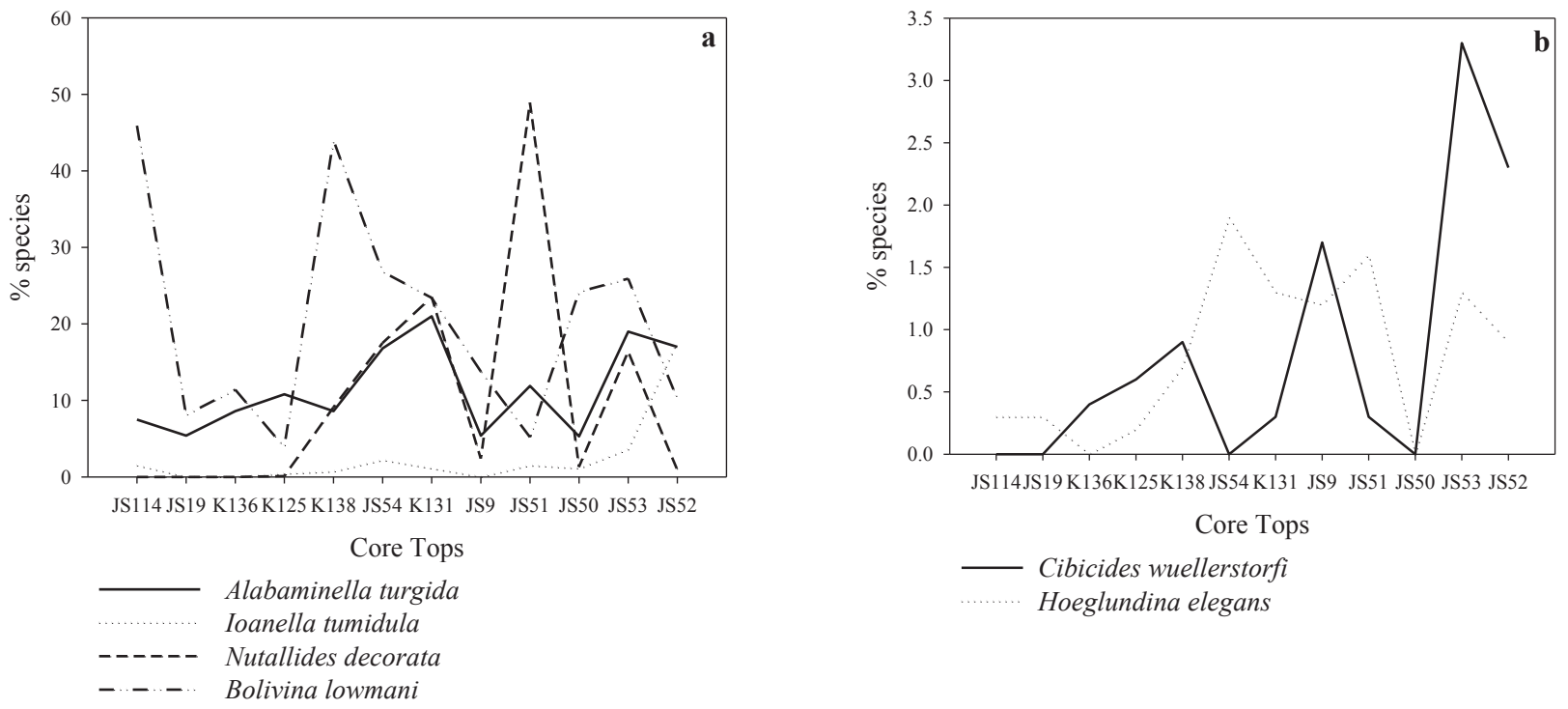

Figure 4. Core-top distribution of Factor 2 assemblage. a) Species with higher scores: Alabaminella turgida, Ioanella tumidula, Nuttalides decorata, Bolivina lowmani, b) Other species abundant in this factor: Cibicides wuellerstorfi, Hoeglundina elegans.

Table 5. Eigenvalues and factor loadings for down-core samples.

\begin{tabular}{rrrrc}
\hline & Eigenvalue & $\begin{array}{c}\text { \% Total } \\
\text { variance }\end{array}$ & $\begin{array}{c}\text { Cumulative } \\
\text { eigenvalue }\end{array}$ & $\begin{array}{c}\text { Cumulative } \\
\%\end{array}$ \\
\hline 1 & 35.41598 & 82.36275 & 35.41598 & 82.36275 \\
2 & 3.66996 & 8.53479 & 39.08594 & 90.89754 \\
3 & 2.97063 & 6.90843 & 42.05657 & 97.80597 \\
\hline
\end{tabular}

(-0.52) and Ioanella tumidula (-0.49). As explained above, $N$. decorata has been considered as characteristic of CMW and the abyssal Gulf. In our core-tops, this species has its upper depth limit at $1245 \mathrm{~m}$ (similar to the one found by Denne and Sen Gupta, 1993, in the northwestern Gulf), and it is the second most abundant species in our samples, after B. lowmani.

Factor $2 \mathrm{~d}-\mathrm{c}$ ( $8.5 \%$ of total variance) is represented by Alabaminella turgida (score 5.9) and, to a minor extent, by Ioanella tumidula (0.7), Biloculinella irregularis (0.3), Cornuloculina inconstans (0.3), Nuttallides decorata (0.2), Globocassidulina subglobosa (0.06), Francesita advena (0.02), Pyrgo nasuta (0.02), Cibicides wuellerstorf (0.02), and Oridorsalis umbonatus (0.005). Alabaminella turgida, the main species of this factor, is one of the most abundant species in the deepest Gulf, and is characteristic of welloxygenated waters (Phleger and Parker, 1951; Parker, 1954; Pflum and Frerichs, 1976; Denne and Sen Gupta, 1991, 1993, 2003). The rest of the species with positive scores on Factor $2 \mathrm{~d}-\mathrm{c}$ are mainly found in the Pleistocene section of the cores (Figure 6), and represent a mixture of porcelaneous, high-Mg-calcitic species $(B$. irregularis, $C$. inconstans, $P$. nasuta $)$ and deep-water hyaline species $(C$. wuellerstorfi, O. umbonatus, $N$. decorata). Bolivina lowmani shows a strong negative score (-1.48).

Factor 3d-c shows positive scores (Figure 7) for 6 species (B. lowmani, A. turgida, N. decorata, G. subglobosa, H. elegans, and I. tumidula) and the strongest negative scores: C. inconstans $(-0.55), B$. irregularis $(-0.53)$, and $F$. advena $(-0.40)$.

Bolivina lowmani, A. turgida, N. decorata, and $G$. subglobosa are the four most abundant species at depths greater than $\sim 2000 \mathrm{~m}$ in the present southwestern Gulf of Mexico, as well as in the northwestern Gulf (Phleger and Parker, 1951, Phleger, 1960; Dignes, 1979) and the Caribbean (Gaby and Sen Gupta, 1985; Bertrand, 1986; Galluzzo et al., 1990). The species with negative scores are the LGM dissolution-prone fauna of Factor 2 d-c.

The distribution of these three factors is different in each core (Table 6). Core JS 51 (Figure 2) contains a sequence of $160 \mathrm{~cm}$ reaching up to the Y2 subzone. All of the sequence is characterized by high loadings of Factor $1 \mathrm{~d}-\mathrm{c}$, implying there is no change in the foraminiferal assemblage (Nuttalides decorata). The Y and earliest Z2 subzones of core JS 53 show high loadings of Factor $2 \mathrm{~d}$-c, indicating that during this time interval the central waters of the Gulf, around $2700 \mathrm{~m}$ depth, were dominated by the Alabaminella turgida assemblage while the rest of the Holocene is characterized by the Bolivina lowmani assemblage (Factor $3 \mathrm{~d}-\mathrm{c})$. The Pleistocene to early Holocene part of core JS 54 (Z2 subzone) is characterized by Factor $1 \mathrm{~d}$-c while the late Holocene part (Z1 subzone) is dominated by Factor 3 d-c.

\section{Discussion}

Two modern assemblages of benthic foraminifera are clearly recognized in deep-bathyal and abyssal sediments 
Table 6. Factor loadings for down-core samples H (Holocene), P (Pleistocene). Factor Loadings (Varimax normalized) Extraction: Principal components.

\begin{tabular}{|c|c|c|c|c|}
\hline & & Factor 1 & Factor 2 & Factor 3 \\
\hline \multirow{6}{*}{$\mathrm{H}$} & $51-0$ & 0.9231 & 0.22432 & 0.28732 \\
\hline & $51-10$ & 0.8737 & 0.2477 & 0.36349 \\
\hline & $51-20$ & 0.80369 & 0.1387 & 0.57466 \\
\hline & $51-30$ & 0.78297 & 0.20926 & 0.57586 \\
\hline & $51-40$ & 0.74035 & 0.20746 & 0.6327 \\
\hline & $51-50$ & 0.90841 & 0.21669 & 0.35315 \\
\hline \multirow{10}{*}{$\mathrm{P}$} & $51-60$ & 0.87874 & 0.34457 & 0.31736 \\
\hline & $51-70$ & 0.93555 & 0.25534 & 0.23702 \\
\hline & $51-80$ & 0.83535 & 0.45333 & 0.30041 \\
\hline & $51-90$ & 0.8674 & 0.34951 & 0.3465 \\
\hline & $51-100$ & 0.73579 & 0.22142 & 0.62733 \\
\hline & $51-110$ & 0.73277 & 0.30082 & 0.60329 \\
\hline & $51-130$ & 0.68069 & 0.27902 & 0.62689 \\
\hline & $51-140$ & 0.82915 & 0.16496 & 0.49877 \\
\hline & $51-150$ & 0.6857 & 0.32571 & 0.63189 \\
\hline & $51-160$ & 0.7112 & 0.37767 & 0.58423 \\
\hline \multirow{7}{*}{$\mathrm{H}$} & $53-0$ & 0.28341 & 0.36409 & 0.88203 \\
\hline & $53-9$ & 0.28214 & 0.57505 & 0.75324 \\
\hline & $53-20$ & 0.37231 & 0.32941 & 0.8473 \\
\hline & $53-30$ & 0.38978 & 0.3377 & 0.82572 \\
\hline & $53-40$ & 0.42991 & 0.50014 & 0.74544 \\
\hline & $53-50$ & 0.26435 & 0.63278 & 0.71598 \\
\hline & $53-60$ & 0.44867 & 0.7964 & 0.38011 \\
\hline \multirow{7}{*}{$\mathrm{P}$} & $53-70$ & 0.24843 & 0.91807 & 0.27133 \\
\hline & $53-80$ & 0.37139 & 0.85569 & 0.27906 \\
\hline & $53-90$ & 0.26028 & 0.90469 & 0.28841 \\
\hline & $53-100$ & 0.47335 & 0.78436 & 0.29365 \\
\hline & $53-110$ & 0.3397 & 0.86524 & 0.32523 \\
\hline & $53-120$ & 0.34184 & 0.86517 & 0.26695 \\
\hline & $53-130$ & 0.21011 & 0.9345 & 0.25575 \\
\hline \multirow{8}{*}{$\mathrm{H}$} & $54-0$ & 0.31957 & 0.27756 & 0.89799 \\
\hline & $54-10$ & 0.45472 & 0.46989 & 0.74121 \\
\hline & $54-20$ & 0.46182 & 0.18233 & 0.85499 \\
\hline & $54-30$ & 0.3023 & 0.28707 & 0.89435 \\
\hline & $54-40$ & 0.68429 & 0.24249 & 0.67966 \\
\hline & $54-50$ & 0.71178 & 0.49289 & 0.48873 \\
\hline & $54-60$ & 0.80466 & 0.44438 & 0.38452 \\
\hline & $54-70$ & 0.81045 & 0.47125 & 0.32321 \\
\hline \multirow{4}{*}{$\mathrm{P}$} & $54-80$ & 0.79011 & 0.50655 & 0.31845 \\
\hline & $54-90$ & 0.8386 & 0.48014 & 0.22024 \\
\hline & $54-100$ & 0.82936 & 0.46951 & 0.28426 \\
\hline & $54-110$ & 0.86875 & 0.41812 & 0.22505 \\
\hline
\end{tabular}

Table 7. Factor scores for down-core samples.

Factor Scores (Varimax normalized) Extraction: Principal components

\begin{tabular}{|c|c|c|c|}
\hline Factor 1 & Factor 2 & Factor 3 & Species \\
\hline-0.520715 & 5.87532 & 1.272981 & Alabaminella turgida \\
\hline-0.136135 & -0.12706 & -0.322489 & Alliatina $\mathrm{sp}$ \\
\hline-0.103293 & -0.20135 & -0.349119 & Bolivina spp \\
\hline-0.976955 & -1.48219 & 5.80151 & B.lowmani \\
\hline-0.167808 & -0.30136 & -0.201467 & Bulimina aculeata \\
\hline-0.114377 & -0.28414 & -0.284841 & B. alazanensis \\
\hline-0.110745 & -0.29777 & -0.250602 & B. mexicana \\
\hline-0.004404 & 0.06282 & 0.284103 & Globocassidulina subglobosa \\
\hline-0.141741 & -0.18462 & -0.179735 & G. sp \\
\hline-0.1584 & 0.01881 & -0.121419 & Cibicides wuellerstorfi \\
\hline-0.192581 & -0.08462 & -0.019906 & Cibicidoides $\mathrm{sp}$ \\
\hline-0.13144 & -0.26214 & -0.228562 & C. mundulus \\
\hline-0.104661 & 0.33212 & -0.546921 & Cornuloculina inconstans \\
\hline-0.091557 & -0.3095 & -0.269348 & Coryphostoma subspinensis \\
\hline-0.10642 & -0.02422 & -0.268427 & Eggerella bradyi \\
\hline-0.10052 & -0.31492 & -0.119329 & Epistominella exigua \\
\hline-0.048002 & -0.29412 & -0.279927 & E. vitrea \\
\hline-0.187141 & 0.01971 & -0.404333 & Francesita advena \\
\hline-0.205615 & -0.26626 & -0.062128 & Glomospira charoides \\
\hline-0.13581 & -0.30892 & -0.013805 & Gyroidinoides polius \\
\hline-0.1874 & -0.24545 & -0.186902 & G. sp 1 \\
\hline-0.017026 & -0.25941 & -0.265178 & G. $\operatorname{sp} 2$ \\
\hline-0.100343 & -0.37994 & 0.194361 & Hoeglundina elegans \\
\hline-0.491116 & 0.67247 & 0.1921 & Ioanella tumidula \\
\hline-0.162841 & -0.18693 & -0.307176 & Melonis pompilioides \\
\hline-0.002824 & 0.33451 & -0.532868 & Biloculinella irregularis \\
\hline 6.077148 & 0.21256 & 0.910969 & Nuttalides decorata \\
\hline-0.105409 & -0.37949 & -0.092758 & Osangularia culter \\
\hline-0.112729 & 0.00475 & -0.343378 & Oridorsalis umbonatus \\
\hline 0.089207 & -0.08044 & -0.271356 & $O . \operatorname{sp~} 1$ \\
\hline-0.116026 & -0.23512 & -0.127233 & Pullenia subspherica \\
\hline-0.144682 & -0.19971 & -0.252358 & P. sp \\
\hline-0.195534 & 0.01924 & -0.313539 & Pyrgo nasuta \\
\hline-0.15952 & -0.1263 & -0.277673 & Quinqueloculina bosciana \\
\hline-0.178826 & -0.04046 & -0.12443 & Q. venusta \\
\hline-0.15523 & -0.08407 & -0.173469 & Q. sp7 \\
\hline-0.084813 & -0.06898 & -0.377979 & Q. $\operatorname{sp~} 8$ \\
\hline-0.069897 & -0.15336 & -0.342098 & Q. spp \\
\hline-0.06656 & -0.11371 & -0.390179 & Robertinoides bradyi \\
\hline-0.077259 & -0.25577 & -0.355092 & Uvigerina peregrina dirupta \\
\hline
\end{tabular}



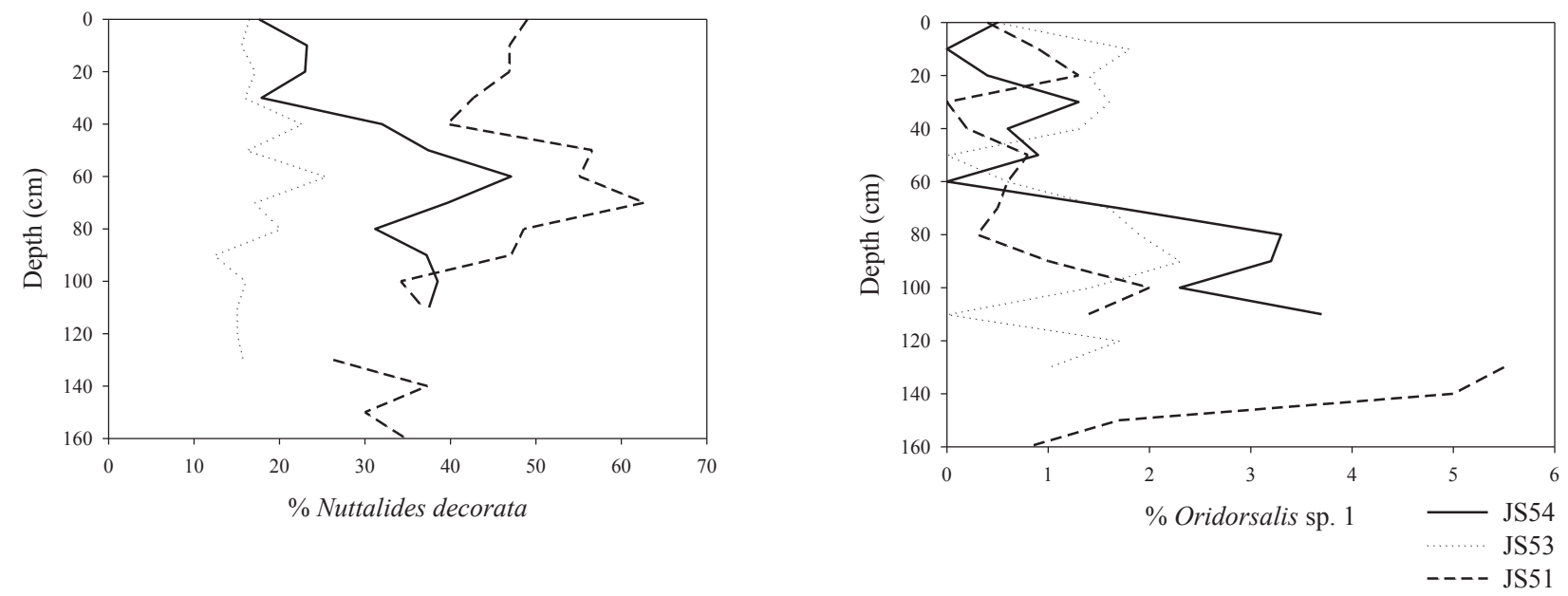

Figure 5. Down-core distribution of characteristic species of Factor 1: Nuttalides decorata, Oridorsalis sp 1.
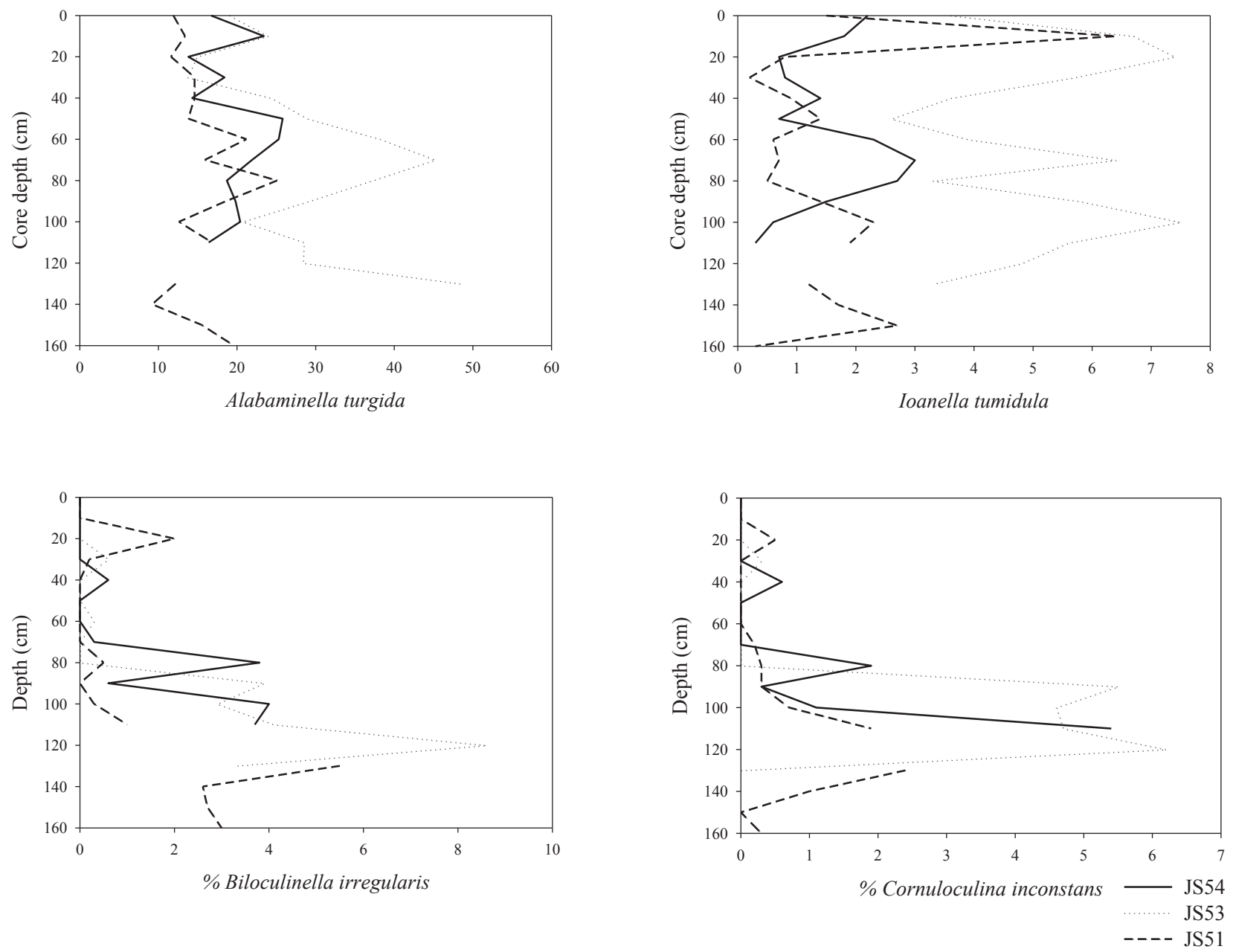

Figure 6. Down-core distribution of characteristic species of Factor 2: Alabaminella turgida, Ioanella tumidula, Biloculinella irregularis, Cornuloculina inconstans. 

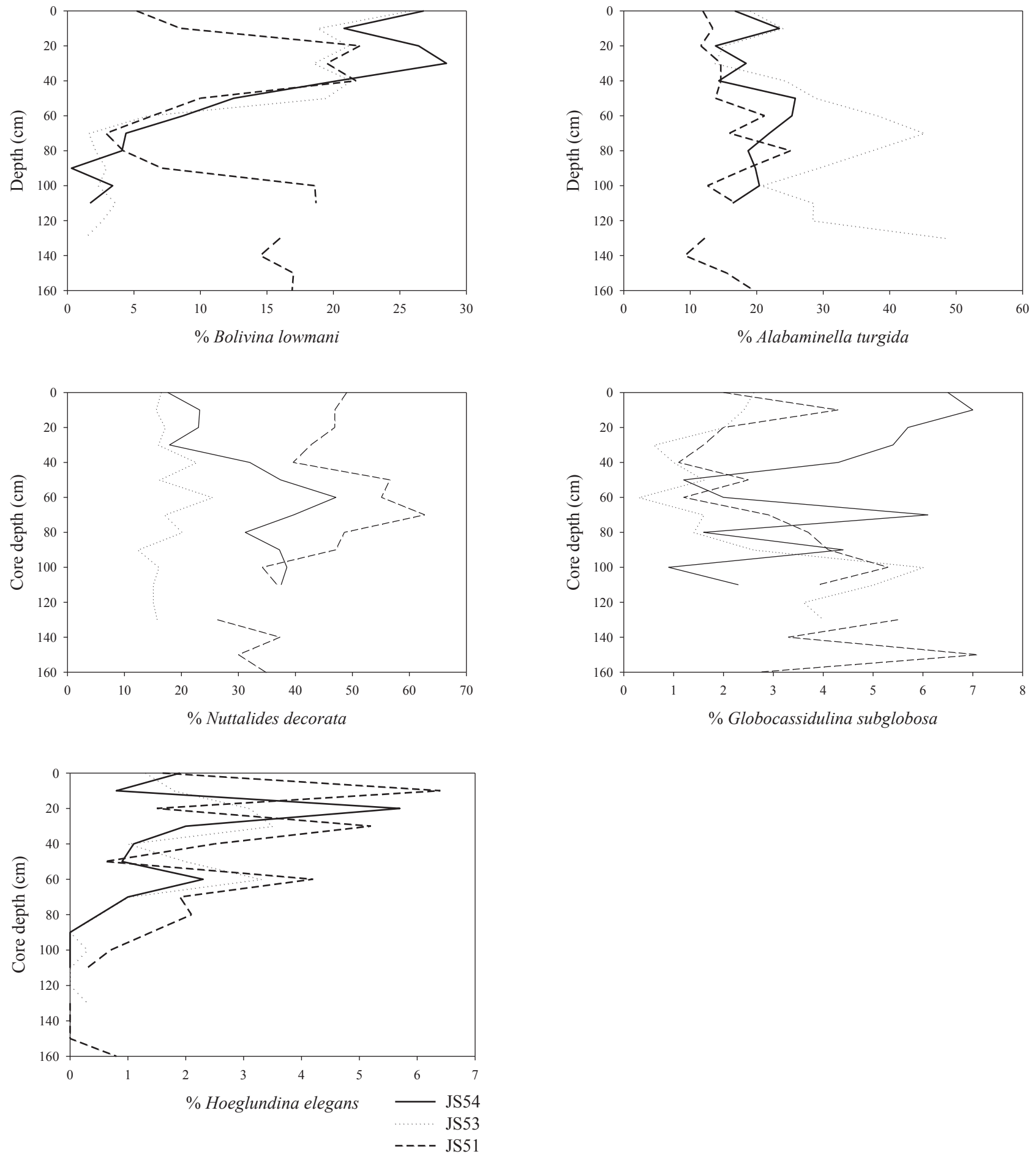

Figure 7. Down-core distribution of characteristic species of Factor 3: Bolivina lowmani, Alabaminella turgida, Nuttalides decorata, Globocassidulina subglobosa, Hoeglundina elegans.

of the southwestern Gulf of Mexico. One (shallower than $1700 \mathrm{~m}$ ) contains species related to AAIW and CMW; the other is a deeper fauna related to NADW. Most of the species found in the modern NADW assemblage were also present in the late Pleistocene. However, important differences can be recognized. The results of factor analysis indicate that during the late Pleistocene (LGM and deglaciation), the benthic foraminiferal fauna between $\sim 2000$ and $2250 \mathrm{~m}$ was dominated by the $N$. decorata assemblage, while the assemblages at depths $\sim 2750 \mathrm{~m}$ were characterized by the A. turgida assemblage.

The A. turgida assemblage (Factor $2 \mathrm{~d}-\mathrm{c}$ ) is composed 
of the most oxygen-sensitive species and a group of dissolution-prone species. Among the latter, B. irregularis has been particularly recognized as an indicator of a lesscorrosive, well-oxygenated water mass present in the Caribbean and the Gulf of Mexico during the Pleistocene (Machain-Castillo et al., 1998; Denne and Sen Gupta, 2003). Such a dissolution-prone fauna would thrive if a less corrosive glacial NADW (GNADW) entered the Gulf of Mexico via the Caribbean Sea and filled the deeper parts of the basin, thus modifying the GNADW. This modified GNADW permitted the proliferation and preservation of the $A$. turgida assemblage in the central Gulf below 2500 $\mathrm{m}$. At shallower depths ( 2000-2250 m), the $N$. decorata fauna was dominant, but still included the dissolution-prone species (B. irregularis, C. inconstans). Nuttallides decorata has also been associated with periods of low-carbonate dissolution (Dignes, 1979), and is probably intolerant of low-oxygen concentrations, since its abundance decreases near river deltas (Pflum and Frerichs, 1976); this is one of the species with positive scores on Factor $2 \mathrm{~d}-\mathrm{c}$.

As the upper GNADW shut down and modern NADW started flowing, less-oxygenated waters entered the Gulf and the most dissolution-prone species (B. irregularis, $C$. inconstans, and $F$. advena) retreated, first from the deepest areas (JS 53), probably due to the lack of water exchange below the sill depth. Alabaminella turgida and $N$. decorata persisted in the Holocene NADW, but there are noticeable differences in their history. The abundance of $A$. turgida decreased in the less-oxygenated Holocene waters of the Gulf, while $N$. decorata increased in abundance, particularly in the eastern Gulf. The eastern Gulf is bathed by NADW, with decreasing oxygen levels away from the Yucatan Channel. Thus, the most oxygenated waters in the Gulf below sill depth are the ones closest to the Yucatan carbonate platform. For our three cores, the JS 51 site is the closest to the Yucatan Channel, and should have the highest dissolved-oxygen concentration (Rivas et al., 2005). Dissolved oxygen in bottom water was not measured at these locations. However, Martínez-Trápaga (1990) measured $\mathrm{CaCO}_{3}$ content in the sediments, and found a slight increase in carbonate in core JS $51(27.4 \%)$ compared to the other two (JS 53-26\%; JS 54-23.8\%). As NADW moves to the west, it mixes with local water and loses oxygen (McLlelan and Nowlin, 1963; Rivas et al., 2005), and sets the scene for the settlement of species such as Bolivina spp., which are characteristic of lower-oxygen environments in the central and western Gulf.

\section{Conclusions}

Modern benthic foraminiferal faunas in the bathyal and abyssal southwestern Gulf of Mexico can be separated into an AAIW-CMW assemblage and a NADW assemblage at about $1700 \mathrm{~m}$ water depth. This AAIW-CMW assemblage is similar to that found in the northern Gulf, and is characterized by the association of B. lowmani, B. aculeata, A. turgida, G. subglobosa, E. exigua, and E. vitrea, with lesser abundances of B. albatrossi, B. alazanensis, B. mexicana, G. polius, and $O$ culter. North Atlantic Deep Water hosts an assemblage dominated by $N$. decorata, $B$. lowmani, A. turgida and I. tumidula, species that are also predominant in the deep northern Gulf of Mexico and the Caribbean.

The stratigraphic distribution of benthic foraminiferal assemblages in the central southwestern Gulf of Mexico reflects the oceanographic changes since LGM.

Concomitant with changes in the oxygen and $\mathrm{CO}_{2}$ content of the upper GNADW, benthic foraminiferal faunas during the late Pleistocene were dominated by species with preference for well-oxygenated waters and substrates with relatively high carbonate content. During the Holocene, however, the deeper Gulf of Mexico became filled with a more corrosive, less-oxygenated NADW, which caused the virtual disappearance of dissolution-prone species $(B$. irregularis, $C$. inconstans) and the restriction of the $N$. decorata assemblage to the more carbonated and oxygenrich areas of the eastern Gulf, closer to the Yucatan Channel.

\section{Acknowledgments}

The authors express their thanks to the scientific staff and crew of the O/V Justo Sierra for their help in collecting the JS samples, and to Daniel Sundeen for allowing the sampling of the K cores.

\section{References}

Aldeco-Ramírez, J., Monreal-Gómez, M.A., Signoret-Poillon, M., Salas de León, D.A.,Hernández-Becerril, D.U., 2009, Occurrence of a subsurface anticyclonic eddy, fronts, and Trichodesmium spp. over the Campeche Canyon region, Gulf of Mexico: Ciencias Marinas, 35, 333-344.

Bertrand, R.P., 1986, Late Quaternary benthic foraminifera of the Colombia Basin and Cayman Through, Caribbean Sea: Baton Rouge, USA, Louisiana State University, M.Sc. Thesis, 185 p.

Boyle, E.A., 1997, Characteristics of the deep ocean carbon system during the past 150000 years: $\sum \mathrm{CO}_{2}$ distributions, deep water flow patterns, and abrupt climate change: Proceedings of the National Academy of Sciences of the United States of America, 94, 8300-8307.

Culver, S.J., Buzas, M.A., 1981, Distribution of Recent benthic foraminifera in the Gulf of Mexico: Smithsonian Contributions to the Marine Sciences, 8, 1-898.

Culver, S.J., Buzas, M.A., 1983, Recent benthic foraminiferal provinces in the Gulf of Mexico: The Journal of Foraminiferal Research, 13, 21-31.

Curry, W.B., Duplessy, J.C., Labeyrie, L.D., Shackleton, N.J., 1988, Changes in the distribution of $\delta^{13} \mathrm{C}$ of deep water $\sum \mathrm{CO}_{2}$ between the Last Glaciation and the Holocene: Paleoceanography, 3, 317-342.

Denne, R.A., Sen Gupta, B.K., 1991, Association of bathyal foraminifera with water masses in the northwestern Gulf of Mexico: Marine Micropaleontology, 17, 173-193.

Denne, R.A., Sen Gupta, B.K., 1993, Matching of benthic foraminiferal depth limits and water-mass boundaries in the northwestern Gulf of Mexico; an investigation of species occurrences: Journal of 
Foraminiferal Research, 23, 108-117.

Denne, R.A., Sen Gupta, B.K., 2003, The benthic foraminiferal record from the bathyal Gulf of Mexico during the last glacial-postglacial transition, in Olson, H.C., Leckie, R.M. (eds.), Micropaleontologic proxies for Sea-Level Change and Stratigraphic Discontinuities: Tulsa, Oklahoma, USA, SEPM Special Publication, 75, 63-79.

Dignes, T.W., 1979, Late Quaternary abyssal foraminifera of the Gulf of Mexico: Orono, Maine, USA, University of Maine, Ph. D. Thesis, $176 \mathrm{p}$.

Duplessy, J.C., Shackleton, N.J., Fairbanks, R.G., Labeyrie, L., Oppo, D.W., Kallel, N., 1988, Deepwater source variations during the last climatic cycle and their impact on the global deepwater circulation: Paleoceanography, 3, 343-360.

Flower, B.P., Kennett, J.P., 1990, The Younger Dryas Cool Episode in the Gulf of Mexico: Paleoceanography, 5, 949-961.

Gaby, M.L., Sen Gupta, B.K., 1985, Late Quaternary benthic foraminifera of the Venezuela Basin: Marine Geology, 68, 125-144.

Galluzzo, J.J., Sen Gupta, B.K. Pujos, M., 1990, Holocene deep-sea foraminifera of the Grenada Basin: Journal of Foraminiferal Research, 20, 195-211.

Haddad, G.A., Droxler, A.W., 1996, Metastable $\mathrm{CaCO}_{3}$ dissolution at intermediate water depths of the Caribbean and western North Atlantic: Implications for intermediate water circulation during the past 200000 years: Paleoceanography, 11, 701-716.

Jian, Z., Wang, L., 1997, Late Quaternary benthic foraminifera and deep-water paleoceanography in the South China Sea: Marine Micropaleontology, 32, 127-154.

Jones, M.H., Sen Gupta, B.K., 1995, Holocene benthic foraminiferal diversity and abundance variations in lower bathyal and abyssal environments, northwestern Gulf of Mexico: Gulf Coast Association of Geological Societies Transactions, 45, 304-311.

Jones, M.H., Sen Gupta, B.K., 1996, Late Pleistocene sedimentation and Meltwater influx in the Central Gulf of Mexico: Foraminiferal signals: Gulf Coast Association of Geological Societies Transactions, 46, 203-211.

Kennett, J.P., Huddlestum, P., 1972, Late Pleistocene paleoclimatology, foraminiferal biostratigraphy and tephrocronology, western Gulf of Mexico: Quaternary Research, 2, 38-69.

Kennett, J.P., Elmstrom, K., Penrose, N., 1985, The last deglaciation in Orca Basin, Gulf of Mexico: high-resolution planktonic foraminiferal changes: Palaeogeography, Palaeoclimatology, Palaeoecology, 50, 189-216.

Kinard, W.F., Atwood, D.K., Giese, G.S., 1974, Dissolved oxygen as evidence for $18{ }^{\circ} \mathrm{C}$ Sargasso Sea Water in the eastern Caribbean Sea: Deep-Sea Research and Oceanographic Abstracts, 21, 79-82.

Lynch-Stieglitz, J., Adkins, J.F., Curry, W.B., Dokken, T., Hall, I.R., Herguera, J.C., Hirschi, J.J.-M., Ivanova, E.V., Kissel, C., Marchal, O., Marchitto, T.,M., McCave, I.N., McManus, J.F., Mulitza, S., Ninneman, U., Peters, F., Yu, E-F., Zahn, R., 2007, Atlantic Meridional Overturning Circulation During the Last Glacial Maximum: Science, 316, 66-69.

Machain-Castillo, M.L., Sen Gupta, B.K., Alcalá-Herrera, J.A., 1998, Late Quaternary change in deep-bathyal and abyssal waters of the Gulf of Mexico; preservation record of the foraminifer Biloculinella irregularis: Journal of Foraminiferal Research, 28, 95-101.

Marchitto, T.M., Broecker, W.S., 2006, Deep water mass geometry in the glacial Atlantic Ocean: A review of constraints from the paleonutrient proxy $\mathrm{Cd} / \mathrm{Ca}$ : Geochemistry Geophysics Geosystems, 7, 1-16.

Martínez-Trápaga, R., 1990, Fluctuaciones climáticas en el sur del Golfo de México durante el Cuaternario tardío, evidenciadas por asociaciones de Foraminíferos Planctónicos: México, D. F., Universidad Nacional Autónoma de México, M.Sc. Thesis, 141 p.

McLellan, H.J., Nowlin, W.D.Jr., 1963, Some features of the deep water in the Gulf of Mexico: Journal of Marine Research, 21, 233-245.

Metcalf, W.G., 1976, Caribbean-Atlantic Water Exchange Through the Anegada-Jungfern Passage: Journal of Geophysical Research, 81, 6401-6409.
Morrison, J.M., Merrell, W.J., Jr, Key, R.M., Key, T.C., 1983, Property Distributions and Deep Chemical Measurements Within the Western Gulf of Mexico: Journal of Geophysical Research, 88, 2601-2608.

Morrison, J.M., Nowlin, W.D.Jr., 1977, Repeated nutrient, oxygen and density sections through the Loop Current: Journal of Marine Research, 35, 105-128.

Murgese, D.S., De Deckker, P., 2007, The Late Quaternary evolution of water masses in the Eastern Indian Ocean between Australia and Indonesia, based on benthic foraminifera faunal and carbon isotopes analyses: Palaeogeography, Palaeoclimatology, Palaeoecology, 247, 382-401.

Nomura, R., 1991, Oligocene to Pleistocene benthic foraminiferal assemblages at Sites 754 and 756, eastern Indian Ocean, in Weissel, J., Alt, J., Peirce, J., Taylor, E., (eds.), Proceedings of the Ocean Drilling Program, Scientific Results: College Station, Texas (Ocean Drilling Program), 121, 31-75.

Nowlin, W.D.Jr., 1972, Winter circulation patterns and property distributions, in Capurro, L.R.A., Reid, J.L., (eds.), Contributions on the Physical Oceanography of the Gulf of Mexico: Houston, Texas, USA, Gulf Publishing Company, 3-51.

Osterman, L.E., 2003, Benthic foraminifers from the continental shelf and slope of the Gulf of Mexico: an indicator of shelf hypoxia: Estuarine, Coastal and Shelf Science, 58, 17-35.

Parker, F.L., 1954, Distribution of the foraminifera in the northeastern Gulf of Mexico: Bulletin of theMuseum of Comparative Zoology-Harvard University, 111, 451-588.

Pflum, C.E., Frerichs, W.E., 1976, Gulf of Mexico deep-water foraminifers: Cushman Foundation for Foraminiferal Research Special Publication, 14, 1-125.

Phleger, F.B., 1960, Ecology and Distribution of Recent Foraminifera: Baltimore, U.S.A., The Johns Hopkins Press, 297 p.

Phleger, F.B., Parker, F.L., 1951, Ecology of Foraminifera, northern Gulf of Mexico: Part 1, Foraminifera distribution, Part 2, Foraminifera species: Geological Society of America Memoir, 46, 1-88.

Poag, C.W., 1981, Ecologic atlas of benthic foraminifera of the Gulf of Mexico: Woods Hole, Massachusetts, U.S.A., Hutchinson Ross Publishing Company, 153 p.

Poag, C.W., 1984, Distribution and ecology of deep-water benthic foraminifera in the Gulf of Mexico: Palaeogeography, Palaeoclimatology, Palaeoecology, 48, 25-37.

Rivas, D., Badan, A., Ochoa, J., 2005, The ventilation of the deep Gulf of Mexico: Journal of Physical Oceanography, 35, 1763-1781.

Schmiedl, G., Mackensen, R.A., Müller, P.J., 1997, Recent benthic foraminifera from the eastern South Atlantic Ocean: Dependence on food supply and water masses: Marine Micropaleontology, 32, 249-287.

Schroeder, W.W., Berner Jr., L., Nowlin Jr., W.D., 1974, The Oceanic Waters of the Gulf of Mexico and Yucatan Strait During July 1969: Bulletin of Marine Science, 24, 1-19.

Sen Gupta, B.K., Smith, L.E., Machain-Castillo, M.L., 2009, Foraminifera of the Gulf of Mexico, in Tunnell Jr, J.W., Felder, D.L., Earle, S.A. (eds.), Gulf of Mexico origin, waters, and biota: College Station, Texas, U.S.A., A\&M University Press, 87-129.

Vidal, V.M.V., Vidal, F.V., Hernández, A.F., Meza, E., Zambrano, L., 1994, Winter water mass distributions in the western Gulf of Mexico affected by colliding anticyclonic ring: Journal of Oceanography, $50,559-588$

Manuscript received: September 25, 2009.

Corrected manuscript received: October 8, 2010.

Manuscript accepted: November 10, 2010. 
Appendix 1. List of species used in core-tops factor analysis.

Alabaminella turgida (Phleger and Parker, 1951)

Bolivina albatrosssi Cushman, 1922

Bolivina lowmani Phleger and Parker, 1951

Bolivina ordinaria Phleger and Parker, 1951

Bulimina aculeata d'Orbigny, 1826

Bulimina alazanensis Cushman, 1927

Bulimina mexicana Cushman, 1922

Cassidulina neocarinata Thalman, 1950

Cassidulina nocrossi australis Phleger and Parker, 1951

Cibicides wuellerstorfi (Schwager, 1866)

Cibicidoides pachydermus (Rzehak, 1886)

Cibicidoides sp

Coryphostoma subspinescens (Cushman, 1922)

Eggerella bradyi (Cushman, 1911)

Elphidium discoidale (d’Orbigny, 1839)

Elphidium sp 1

Epistominella exigua (Brady, 1884)

Epistominella vitrea Parker, Phleger and Pearson, 1953

Gavelinopsis translucens (Phleger and Parker, 1951)

Globocassidulina subglobosa (Brady, 1881)

Globocassidulina cf. C. subglobosa

Glomospira charoides (Jones and Parker, 1860)

Gyroidinoides altiformis (Stewart and Stewart, 1930)

Gyroidinoides polius (Phleger and Parker, 1951)

Gyroidinoides regularis (Phleger and Parker, 1951)

Gyroidinoides sp 1

Gyroidinoides sp 2

Hoeglundina elegans (d'Orbigny, 1826)

Ioanella tumidula (Brady, 1884)

Neocorbina $\mathrm{sp}$

Neocrosbyia minuta (Parker, 1954)

Nonionella $\mathrm{sp}$

Nuttalides decorata (Phleger and Parker, 1951)

Oridorsalis sp 1

Osangularia culter (Parker and Jones,1865)

Planulina exorna Phleger and Parker, 1951

Pullenia subspherica Parr, 1950

\section{Pullenia $\mathrm{sp}$}

Quinqueloculina venusta Karrer, 1868

Quinqueloculina sp 7

Sphaeroidina bulloides d'Orbigny, 1826

Uvigerina laevis Goës, 1896

Uvigerina peregrina Cushman, 1923
Appendix 2. List of species used in down-core factor analysis.

Alabaminella turgida (Phleger and Parker, 1951)

Alliatina sp 1

Biloculinella irregularis (d'Orbigny, 1839)

Bolivina lowmani Phleger and Parker, 1951

Bolivina spp

Bulimina aculeata d'Orbigny, 1826

Bulimina alazanensis Cushman, 1927

Bulimina mexicana Cushman, 1922

Cibicides wuellerstorfi (Schwager, 1866)

Cibicidoides mundulus (Brady, Parker and Jones, 1888)

Cibicidoides sp

Cornuloculina inconstans (Brady, 1879)

Coryphostoma subspinescens (Cushman, 1922)

Eggerella bradyi (Cushman, 1911)

Epistominella exigua (Brady, 1884)

Epistominella vitrea Parker, Phleger and Pearson, 1953

Francesita advena (Cushman, 1922)

Globocassidulina subglobosa (Brady, 1881)

Globocassidulina cf. C. subglobosa

Glomospira charoides (Jones and Parker, 1860)

Gyroidinoides polius (Phleger and Parker, 1951)

Gyroidinoides sp 1

Gyroidinoides sp 2

Hoeglundina elegans (d'Orbigny, 1826)

Ioanella tumidula (Brady, 1884)

Melonis pompilioides (Fichtel and Moll, 1798)

Nuttalides decorata (Phleger and Parker, 1951)

Oridorsalis umbonatus (Reuss, 1885)

Oridorsalis sp 1

Osangularia culter (Parker and Jones, 1865)

Pullenia subspherica, Parr, 1950

Pullenia $\mathrm{sp}$

Pyrgo nasuta Cushman, 1935

Quinqueloculina bosciana d'Orbigny, 1839

Quinqueloculina venusta Karrer, 1868

Quinqueloculina sp 7

Quinqueloculina sp 8

Quinqueloculina spp

Robertinoides bradyi (Cushman and Parker, 1936)

Uvigerina peregrina dirupta Todd, 1948 